\title{
SOLID WASTE MANAGEMENT: BIN ALLOCATION AND RELOCATION BY USING REMOTE SENSING \& GEOGRAPHIC INFORMATION SYSTEM
}

\author{
Sumedh D. Kashid ${ }^{1}$, Ajay D. Nagne ${ }^{2}$, K.V. Kale ${ }^{3}$ \\ ${ }^{1} M$ Tech, Dept. of CS \& IT, Dr. B.A.M.U., Maharashtra, India \\ ${ }^{2}$ Research fellow, Dept. of CS \& IT, Dr. B.A.M.U., Maharashtra, India \\ ${ }^{3}$ Professor, Dept. of CS \& IT, Dr. B.A.M.U., Maharashtra, India
}

\begin{abstract}
Municipal solid waste management requires a better plan for developing cities like Aurangabad, in India. The ecofriendly environment and reduction in cost can be achieved and analyzed with advanced scientific technology like Geographical Information System (GIS). This study uses GIS for investigating adequate number and positions of existing collection bins in one of the urban ward Chelipura, Aurangabad, India. The proposed numbers of collection bins were suggest according to total MSW generation in the ward. Then the optimal positions were found with reference to existing bin locations, road network and population density. The three different proximity distances such as 50m, $75 \mathrm{~m}$ and $100 \mathrm{~m}$ around existing and proposed bins were generated and optimal distance to be found. As a result, the entire area was covered by $100 \mathrm{~m}$ distance around the collection bin. Thus, the proposed model suggested some modifications in existing system and which would recommend best possible collection services.
\end{abstract}

Key Words - Geographic Information System (GIS), Municipal Solid Waste (MSW), optimal location, Remote Sensing (RS), Solid waste, Solid Waste Management (SWM), Waste Bin

\section{INTRODUCTION}

Rapid urbanization and rapid growth in living standards in cities, is the main reason to increase in the quantity and complexity of waste generation. Urbanization is rapidly increasing in developing countries. In India, proportion of population residing in urban areas has reached $27.8 \%$ in 2001. Management of Municipal Solid Waste (MSW) resulting out of rapid urbanization has become a serious issue for the government departments, regulatory bodies and also public in most of the developing cities $[1,2]$.

Unsustainable disposal of solid waste increases the environmental risk. It is a sensitive issue which deals with serious environmental problems in today's world. The present situation of direct dumping of the waste without proper segregation of waste at source level has a very bad impact on environment as well as on human health. Domestic, industrial and waste generated from other sources, they are causing environmental pollution as well as create serious problems for human being [3, 4, 5, and 6]. If this situation is not handled in a proper manner then it would have serious impact on every living organism.

Waste management is the collection, transport, processing, recycling or disposal and management of solid waste. Municipal Solid Waste Management (MSWM) encompasses the functions of collection, transfer, treatment, recycling, resource recovery and disposal of municipal solid waste [7]. The first goal of MSWM is to protect the health of the people, particularly that of having low-income. Other goals include protecting environment, support of economic productivity and providing employment. Achievement of MSWM goals requires better solid waste management systems that will be accepted by the municipality and the people living there in [8, 9, and 10]. Well planned and source segregated SWM helps in safe disposal, reduction of final waste and increase re-use and recycling of waste. On the other hand a poor management system, leads to a dirty environment affecting the well-being of the people residing therein $[11,12]$.

There has been development of new technologies for improving the waste management systems, like GIS is one of the new technologies which have contributed a lot in very less time span to the waste management system. A GIS is different technology from other information systems, because GIS integrates spatial data with the informative data such as query and statistical analysis with the advantages of visual and geographic analysis through maps $[13,14,15,16$, $17,18,19,20]$.

There are no sufficient infrastructure and resources for the SWM in many Urban Councils of the country, and there are no enough and suitable services to dispose most of the solid waste from households and industries. Based on the investigation of literature review, the RS \& GIS technique is a good decision support tool to implement for locating new bins in one of the main urban area 'Chelipura ward' in 
Aurangabad city, India [21, 22]. The objectives of the study are:

1. To review current MSW management practices including waste generation, location of collection bins, type \& size of collection bins and collection frequency of MSW removal from the bins.

2. To find and allocate new collection bins based on MSW generation using GIS technique and

3. To find the optimal proximity distance for the collection bins by generating buffer zone.

Thus, the study helps in analyzing the present MSW collection issues and used as a decision supporting tool for efficient collection of MSW in the ward.

\section{PRESENT SCENARIO OF RESEARCH AREA}

The Aurangabad City is situated in Maharashtra State, India. It is located in south central India. Aurangabad is located on $19^{\circ} 53^{\prime} 14^{\prime \prime} \mathrm{N}$ and $75^{\circ} 20^{\prime} 12^{\prime \prime} \mathrm{E}$. The city has 113 administrative wards with an area of $143 \mathrm{~km} 2$. The city is a tourism hub, surrounded by many historical monuments, including the Ajanta Caves and Ellora Caves, which are UNESCO World Heritage Sites, as well as BibiKaMaqbara. It is the administrative headquarters of the AurangabadDivision or Marathwada region. Aurangabad is titled "The City of Gates" and the strong presence of these can be felt as one drives through the city. Recently, Aurangabad was declared "Tourism Capital of Maharashtra". The city has urban development and area having potential of rapid industrialization. It has an urban population of 12.71 Lakhs as per AMC. The city generates an average amount of MSW is about 450 MT per day. Source segregation of waste is not done. Waste collected from each ward is directly sent to disposal site i.e. Naregaon waste depo. The study is carried out in one of the ward such as 'Chelipura, Aurangabad (ward no. 23)'. The ward map is shown in figure (1).

\section{DESCRIPTION OF THE WARD}

The ward Chelipura has diverse economical group of people and also consists of mixed residential and commercial areas. This is one of the densely populated urban wards in the Aurangabad city. According to Aurangabad Municipal Corporation the population is about 7406 as on 2015. Ward boundary of chelipura is shown in fig- 1 .

\section{MSW GENERATION AND COLLECTION METHODS IN THE WARD}

The MSW generation in the ward is about 8 tonnes per day. Door to door collection method is mostly followed in this ward. There are total four hand carts used for door to door collection. Also one hook loader, one rickshaw and one tipper is use for waste collection. The major waste generation is from 'Vegetable market'. Near about 5-6 ton waste is generated daily from it.The door to door collection services dumps the MSW into the nearby collection bins. That is road side bins. Due to that many times waste is overflowed from bins. So many times waste is openly dump alongside of road.

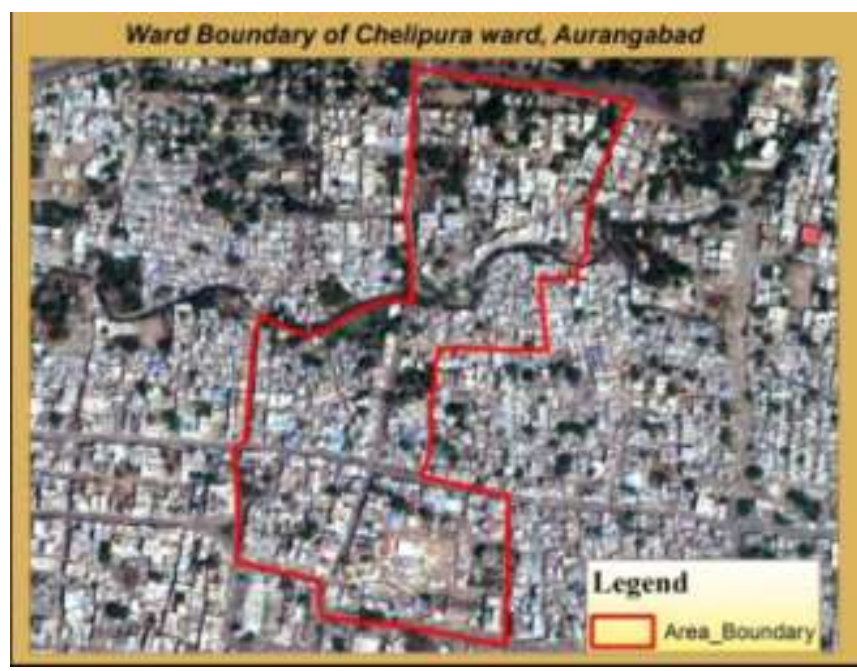

Fig -1: Ward Map

During non-collection period the MSW brim over the collection bins. This is due to the inadequate number of supply of collection bins by the management and the restriction of residence to place the bins in front of their house, thereby only limited number of bins are located in the ward. Owing to the inadequate number of collection bins, there is no proper segregation is carried out and also overflowing of waste bins occurs though the collection frequency is daily once in the morning. This shows the accumulation of waste on the road side. Hence, the study aims to propose new collection bins and their optimal size \& locations with considering existing bins, road network and population settlement by using GIS technique. The proposed location of bins would reduce the present MSW collection service difficulties. There is no proper segregation of MSW and collection method is practiced.

\section{METHODOLOGY}

The aim of this paper is to analyze the present waste management situation in the study area of Aurangabad city and evaluate the problems that arise due to shortcoming of the waste management system. On the basis of the analysis and related literature reviews, a model will be proposed that could be able to improve the waste management situation. The proposed suggestions for amendments in the system through GIS based model would reduce the waste management workload to some extent.

The methodology includes the collection of information about the waste management situations in Aurangabad city and preparing a database about the waste situations of the study area. Analysis of the present waste situation and recognize the problems faced in the system. Detail diagram of methodology is shown in fig. (2).

In the proposed model the waste management issues are considered to solve some of the present situation problems like proper allocation and relocation of waste bins, check for 
unsuitability and proximity convenience to the users, proposal of recyclable waste bins for the required areas and future suggestions.

\subsection{Primary Data}

Primary Data consists of two main things as follows:

1. Google Earth Image

2. GPS Survey Data

Study area image marked on Google Earth and it is exported in .jpeg format. Then this image was imported to ArcCatlog. Then that image was added into ArcMap. Then control points were added that link the known positions of raster dataset with the known positions in map coordinates. Control points are locations that can be accurately identified on the raster dataset and in real-world coordinates. Then register the dataset means save the georeferencing information and make sure that all control points are properly placed. Then transform the raster dataset permanently using rectify option in the georeferencing toolbar.

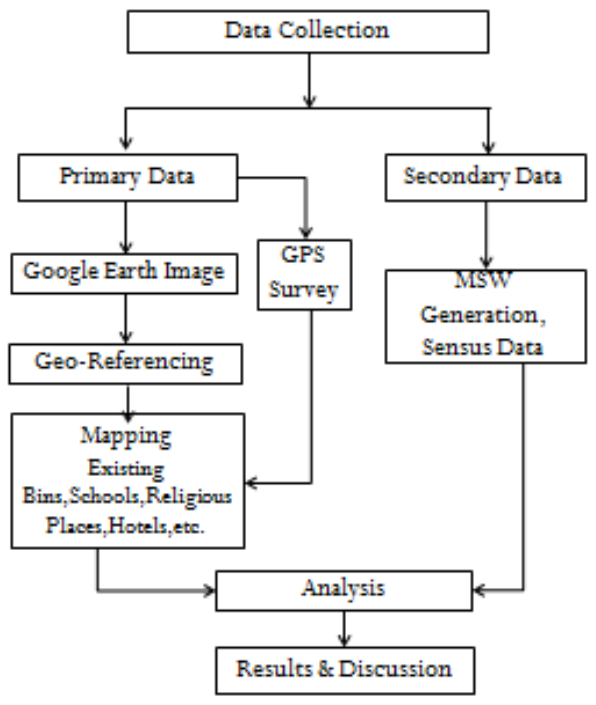

Fig - 2: Methodology

Rectified dataset should have low RMS error. RMS error is one of the most widely used statistics in GIS. RMS error measures how much error there is between two datasets. RMS error usually compares a predicted value and an observed value.

This value describes how consistent the transformation is between the different control points (links). When the error is particularly large, you can remove and add control points to adjust the error. The more control points of equal quality used, the more accurately the polynomial can convert the input data to output coordinates. RMS error can be calculated by using the formula shown in equation (1).

$R M S E=\sqrt{\frac{1}{N} \sum_{i=1}^{N}\left(x_{i}-\hat{x}_{i}\right)^{2}}$
Here we have got RMS error 0.7279 , which is shown in figure (3). As the RMS error is very negligible, accuracy will be more.

\subsection{GPS Survey Data}

Location of existing waste bins, schools, colleges, religious places, hospitals, hotels, shops, etc. we derived locations means Longitude and Latitude of a place by on-site capturing with the use of (Global Positioning System) GPS technology. Here we use smartphone having GPS technology and used GPS coordinate android software for capturing the location. Accuracy we got here in the range of $3 \mathrm{~m}$ to $5 \mathrm{~m}$.

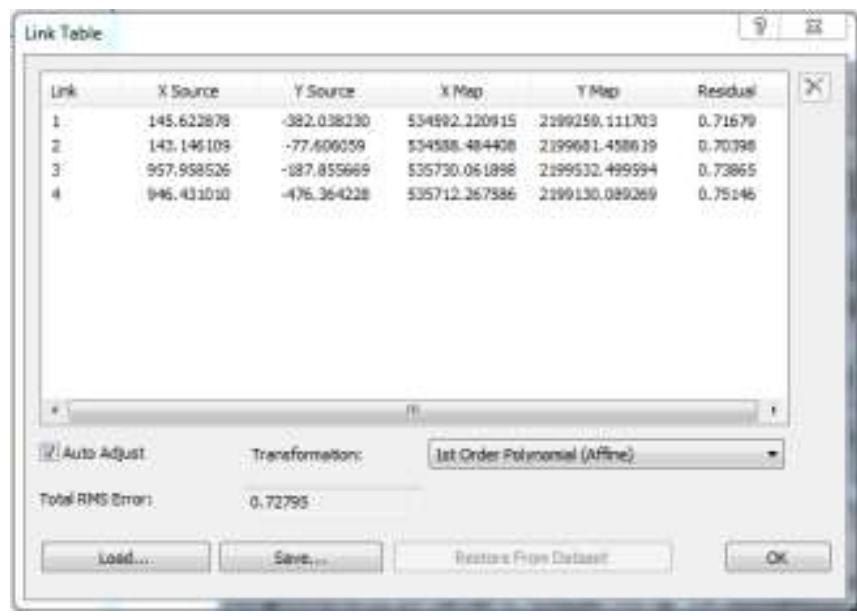

Fig - 3: RMS Error

\subsection{Mapping}

Map the existing bin locations as well as open dumps in the study area. Ward boundary is mapped. We had also mapped religious places, major hotels, hospitals, schools and shops. Figure (4) shows the mapping of existing bin locations and open dumps in the ward. Figure (5) shows the mapping of sensitive areas buildings in the ward.

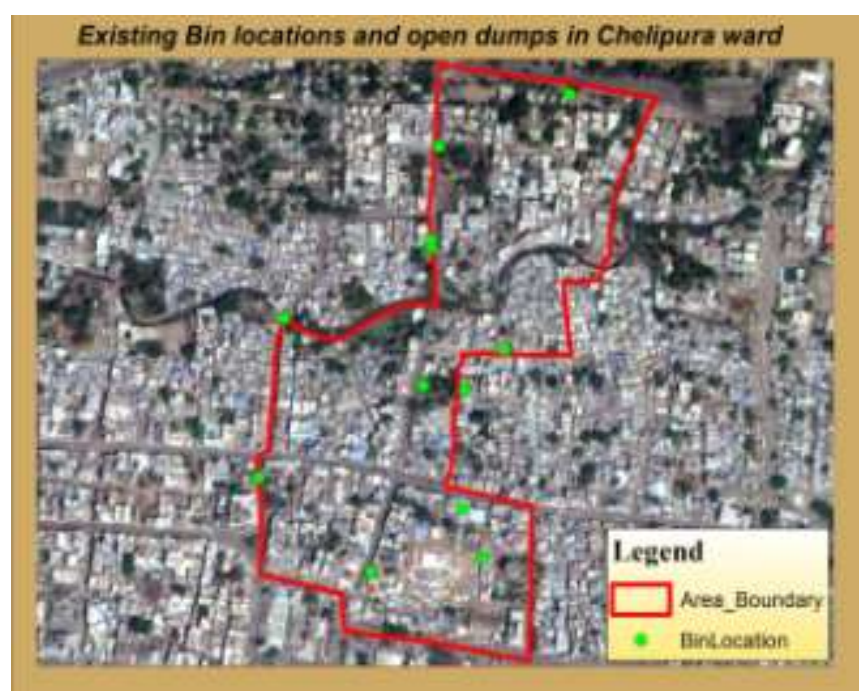

Fig - 4: Mapping of Bins and Open Dumps 


\subsection{Secondary Data}

In cooperation with the Aurangabad Municipal Corporation (AMC), secondary data had been collected. Population of the ward, number of houses in the ward, waste generation per day, ward boundary, number, type and location of waste bins.

Table 1: Ward no 23. Secondary Data

\begin{tabular}{|l|l|l|l|l|}
\hline Population & $\begin{array}{l}\text { No. of } \\
\text { Houses }\end{array}$ & $\begin{array}{l}\text { No. of } \\
\text { Workers }\end{array}$ & Vehicles & $\begin{array}{l}\text { Total waste } \\
\text { generation }\end{array}$ \\
\hline 7406 & 1506 & $\begin{array}{l}\text { M -13 } \\
\text { F - 06 }\end{array}$ & $\begin{array}{l}\text { Pull cart-4 } \\
\text { Rikshaw-1 } \\
\text { Truck-1 }\end{array}$ & 8 MT/day \\
\hline
\end{tabular}

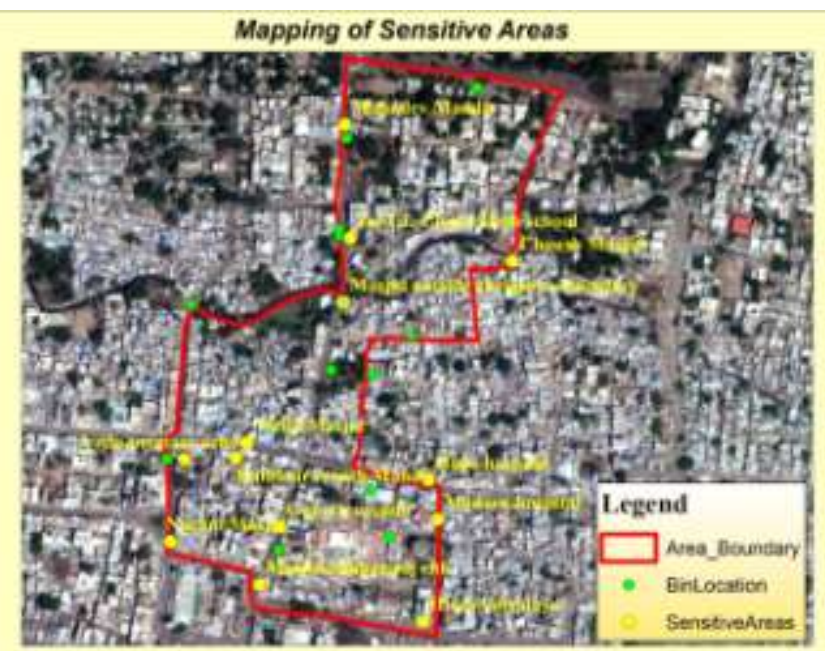

Fig - 5: Mapping of SensitiveAreas Buildings

\section{EXPERimental AnAlysis}

\subsection{Population density}

It can be calculated by using the formula [21],

Population density $=\frac{\text { Total population of ward }}{\text { Total area of ward }}$

By using above formula, the population density of study area is calculated as $37 \mathrm{k} / \mathrm{sq} . \mathrm{km}$.

\subsection{Per capita waste generation}

It can be calculated by using the formula

Per capita waste generation $=\frac{\text { Total waste generation of ward }}{\text { Total population of ward }}$

By using above formula, per capita waste generation of the study area is calculated as $1.08 \mathrm{~kg} / \mathrm{day}$.As it is too high the study shows that it is due to the vegetable market present in that area.It generates 5-6 tonnes waste daily.

\subsection{Number of Waste Bins}

As, we are using circular buffer to calculate service area of bin, so area cover by a bin can be calculated by using formula $\pi \mathrm{r} 2$, where ' $\mathrm{r}$ ' is proximity distance used for creation of buffer. Therefore, minimum number of bins required is given by,

$N=\frac{T \cdot A .}{B \cdot A}$

Where, T.A. $=$ Total service area .

B.A. $=$ Service area covered by a bin (Bin Area).

By using above formula there are minimum 11 bins required for the chelipura ward to cover the whole area.

\subsection{Capacity of a bin}

Capacity of bin can be calculated by using following formula: Minimum capacity of a bin equal's,

$C=(B . A .)^{*} d^{*} f$

Where, B.A. = Service area covered by a bin. $\mathrm{d}=$ Population density

$\mathrm{f}=$ Per capita waste generation

By using the above formula it is found that the minimum capacity of bin should be $300 \mathrm{~kg}$. By considering the population growth it is suggested that bin size should be of capacity 0.5 ton.

\subsection{Waste Bins Within Close Proximity of Sensitive \\ Buildings}

To avoid the inconvenience due to close proximity of bins, a buffer of 20 meters is created around schools, hospitals and religious buildings. After application of the buffer the following results were obtained which can be seen in fig (6).

It can be clearly seen that there are four waste bins which are in the close proximity of sensitive buildings. There is need to replace those bins.

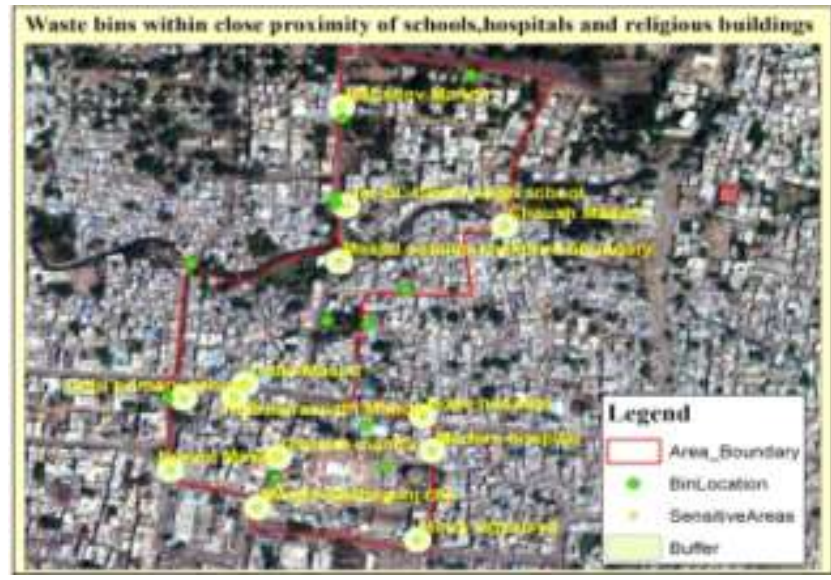

Fig - 6: Waste Bins within Close Proximity OfSchools, Hospitals And Religious Buildings 


\subsection{Creating Buffer Zones around Waste Bins}

We create $50 \mathrm{~m}, 75 \mathrm{~m}$ and $100 \mathrm{~m}$ buffer zones around the existing waste bins and it is found that entire area can be covered by relocating some bins in the ward. Figure7, figure8, figure 9 shows buffer of $50 \mathrm{~m}, 75 \mathrm{~m}, 100 \mathrm{~m}$ around the existing bins and open dumps respectively. By the study of literature survey and field survey it is found that $100 \mathrm{~m}$ distance is appropriate to people.

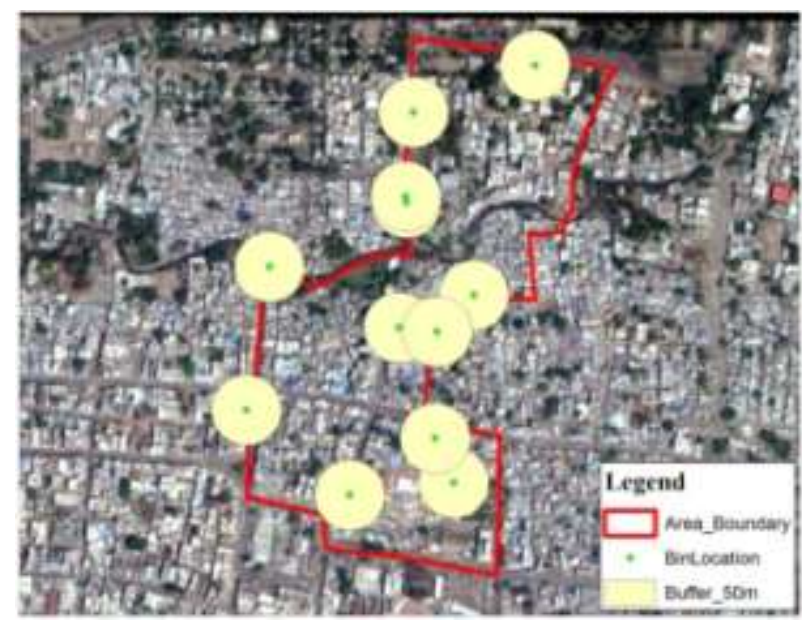

Fig - 7: Existing Collection Bins with 50m Buffer Zone

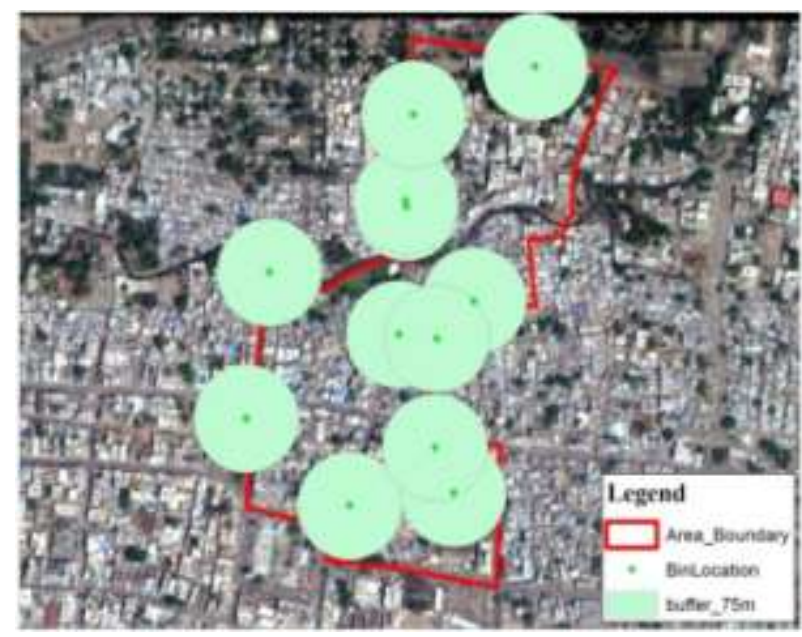

Fig - 8: Existing Collection Bins with $75 \mathrm{~m}$ Buffer zone

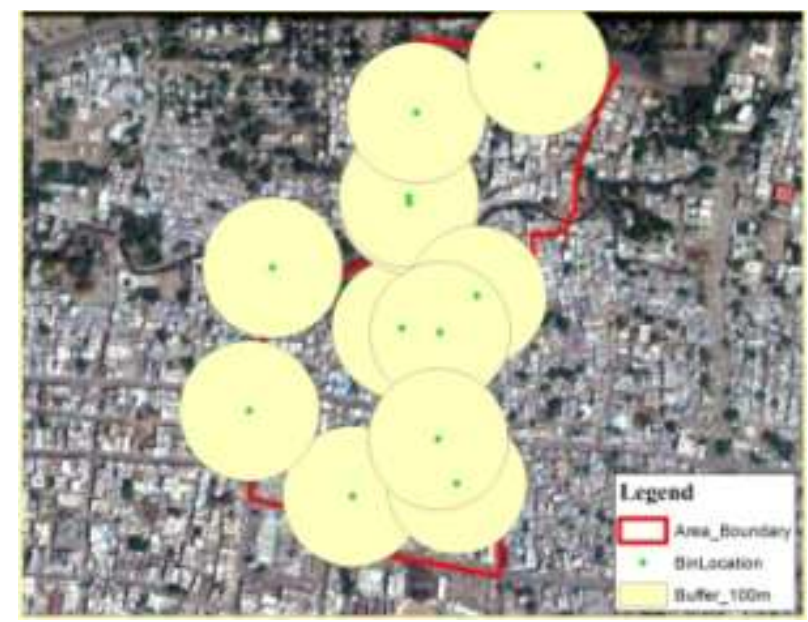

Fig - 9: Existing Collection Bins with 100m Buffer Zone

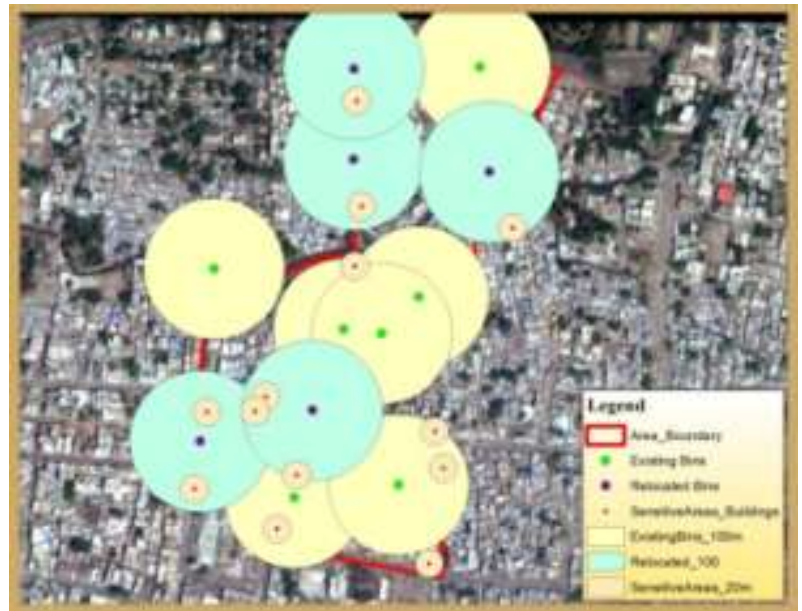

Fig - 10: After Relocation and Allocation of New Bin with $100 \mathrm{~m}$ Buffer Zone

After relocation of five bins almost all the area is covered by $100 \mathrm{~m}$ buffer zone around the bins. Also we can see that no bin is in the proximity distance of $20 \mathrm{~m}$ from sensitive areas building.

\section{CONCLUSION}

The improper management of waste bins produces many health and environment related issues. RS and GIS can be effectively used in the management of solid waste and waste bin management. To avoid open dump of waste, waste bins must be allocated by finding proximity distance convenient to the people. Bin size should be decided according to generation of amount of waste and collection frequency to avoid overflow of bins. On the basis of type of waste generated in particular area, type of bin can be decided.The study analyses the present issues associated to MSW collection services. The present location of the collection bins were analyzed for the different proximity distances in the ward Chelipura, Aurangabad using GIS. To ensure the entire quantity of generated MSW from the ward a new model was proposed with optimal number and location of bins. It was found that the proximity distance of $100 \mathrm{~m}$ by the residents ensures the complete collection of MSW in the ward. The proposed model also helps the municipal authorities in decision making process in the management of MSW. The AMC is planned for source sorted degradable and recyclable waste and for the easy disposal. Also, the quantity of degradable waste is much higher (94\%) than the recyclable waste. Hence, the study recommends the option such as the modification in the design of collection bin for efficient collection of source sorted MSW.

\section{ACKNOWLEDGEMENT}

Author would like to acknowledge and extend our heartfelt gratitude to UGC SAP (II) DRS Phase-I F.No.-3-42/2009; and UGC-BSR Fellowship; and in part DST - NRDMS Srinivasa Ramanujan Geospatial Chair to Department of Computer Science \& IT, Dr. Babasaheb Ambedkar Marathwada University, Aurangabad. 


\section{REFERENCES}

[1] Mr. AnkitVerma, Prof. B.K Bhonde, "Optimisation of Municipal Solid Waste Management of Indore City using GIS," International Journal on Emerging Technologies 5(1): 194-200, 2014.

[2] Sharholy.M, Ahamed.K, Vaishya.RandGupta.R, "Municipal Solid waste characteristics and management inAllahabad", India, Waste Management, 27(4), 2007, pp.490-496.

[3] Ramasamy. SM., Kumanan, C.J. and Palanivel.K. "GIS based solutions for Waste Disposals", GIS Development. Vol...6(12), pp.40-42.

[4] Jha, M.K., Sondhi, O.A.K., Pansare, M.,"Solid waste management - a case study. Indian", Journal of Environmental Protection, 2003, 23, 10, pp 1153-1160.

[5] Kansal, A., "Solid waste management strategies for India", Indian Journal of Environmental Protection, 2002, 22,4, 444-448.

[6] Ray, M.R., Roychoudhury, S., Mukherjee, G., Roy, S., Lahiri, T., "Respiratory and general health impairments of workers employed in a municipal solid waste disposal at open landfill site in Delhi", International Journal of Hygiene and Environmental Health, 2005, 108, 4, pp 255-262.

[7] Robinson, W.D. "The Solid Waste Handbook: A Practical Guide", John Wiley \& Sons, Chichester, 1986.

[8] J. Senthil, S. Vadivel1 and J. Murugesan, "Optimum Location of Dust Bins Using Geo-Spatial Technology: A Case Study of Kumbakonam Town, Tamil Nadu, India",Pelagia Research Library,Advances in Applied Science Research, 3 (5):2997-3003.

[9] Sumedh D. Kashid, Dhananjay B. Nalawade, Ajay D. Nagne, Rajesh K. Dhumal, K.V.Kale, "Solid Waste and Waste Bin Management By Using RS \& GIS: A Review", International Journal of Scientific \& Engineering Research, Volume 6, Issue 4, April-2015.

[10] Ajay D. Nagne, Rajesh K. Dhumal, Amol D. Vibhute, Yogesh D. Rajendra, K. V. Kale, S. C. Mehrotra, "Suitable Sites Identification for Solid Waste Dumping Using RS and GIS Approach: A Case Study of Aurangabad, (MS) India”, IEEE - 2014.

[11] I.A.K.S.Illeperuma, Dr. LalSamarakoon,"Locating Bins using GIS", International Journal of Engineering \& Technology IJET-IJENS Vol:10 No:02, 2010.

[12] Nithya.R, Velumani.A, SenthilKumar.S.R.R, "Optimal Location and Proximity Distance of Municipal Solid Waste Collection Bin Using GIS: a Case Study of Coimbatore City", WSEAS Transactions on Environment and Development, E-ISSN: 2224-3496, Issue 4, Volume 8, 2012.

[13] Johansson O.M., "The effect of dynamic scheduling and routing in a solid waste management system", Vol.26, 2006, pp. 875- 885 .

[14] Kim B.I., Kim S., Sahoo S., "Waste collection vehicle routing problem with time windows", Computers and Operations Research, Vol.33, 2006, pp. 3624-3642.

[15] Sahoo S., Kim S., Kim B.I., KraasB.,Popov J.,"Routing optimization for Waste management, Interfaces", Vol.35, 2005, pp.24-36.
[16] Tavares G., Zsigraiova Z., Semiao V, Carvalho M.A, "Case study of fuel saving through optimization of MSW transportation routes, Management of Environmental Quality", Vol.19, No.4, 2008, pp. 444454.

[17] Ajay D. Nagne, Amol D. Vibhute, BhartiW.Gawali, Suresh C. Mehrotra, "Spatial Analysis of Transportation Network for Town Planning of Aurangabad City by using Geographic Information System”, International Journal of Scientific \& Engineering Research, Volume 4, Issue 7, July 2013.

[18] MaherArebey, M A Hannan, Hassan Basri, R A Begum and Huda Abdullah, "RFID and Integrated Technologies for Solid Waste Bin Monitoring System", Proceedings of the World Congress on Engineering Vol I, London, U.K., 2010.

[19]Caputo A.C. and PelagaggeP.M., "Integrated Geographical Information System (GIS) for urban solid waste management", Advances in Architecture Series, 2000, pp. 159-169.

[20]Ellis S. and Dinsmore Q, "Turning a corner with mapping software", Public Works, vol.136, 2005, pp. 56.

[21] Ajay D. Nagne, Dr. BhartiW.Gawali, "Transportation Network Analysis By Using Remote Sensing And GIS A Review", International Journal of Engineering Research and Applications (IJERA) ISSN: 2248-9622 www.ijera.com Vol. 3, Issue 3, May-Jun 2013, pp.070$07670 \mid \mathrm{P}$ a g e.

[22]Levein van Zon, NalakaSiriwardana, "Garbage in Sri Lanka”, Integrated Resources Management Programme in Wetlands, Sri Lanka, Free University of Amsterdam, the Netherland-2000. 